\title{
Suitability of soil bioengineering techniques in Central America: a case study in Nicaragua
}

\author{
A. Petrone and F. Preti \\ Department of Agriculture and Forestry Engineering, University of Florence, Italy \\ Received: 27 November 2007 - Published in Hydrol. Earth Syst. Sci. Discuss.: 13 February 2008 \\ Revised: 20 August 2008 - Accepted: 1 September 2008 - Published: 21 October 2008
}

\begin{abstract}
In the last few years "D. I. A. F." (Department of Agriculture and Forestry Engineering of Florence University), has been testing the effectiveness of soil bioengineering techniques in Central America. The focus of the present study was to find out which native plants were most suited for soil bioengineering purposes, particularly in the realization of riverbank protection in Nicaragua. Furthermore, we have also been aiming at economic efficiency.

These techniques are appropriate for sustainable watershed management especially in underdeveloped countries. Concerning the plants to be used we experimented four native species. Gliricidia Sepium, Cordia dentata and Jatropha curcas are suitable for soil bioengineering more than Bursera Simaruba. Economically speaking, the sustainability of such interventions in underdeveloped countries, has been shown by the evaluation of the cost of riverbank protection using vegetated crib-walls in Nicaragua compared to the cost in different contexts.
\end{abstract}

\section{Introduction}

Soil bioengineering has been used frequently in Europe in the last years, especially in the Alps and Mediterranean regions, indeed the widespreading phase of the 1990's has passed.

Because of this experience, some research teams have begun testing the use of soil bioengineering techniques in "underdeveloped countries".

Currently, experiments in Nepal (Florineth, 2004; Ghimire and Karki, 2004; Rauch et al., 2004; Lammeranner et al., 2005), in Brazil (Sutili et al., 2004), and in Nicaragua (Petrone and Preti, 2005; Ferrari et al., 2005; Petrone et al., 2006), are still in course. Soil bioengineering is based on two

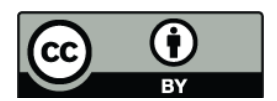

Correspondence to: A. Petrone (alessandro.petrone@unifi.it) fundamental issues independently from a world wide application. The basic for each application is the suitability of soil bioengineering plants and secondly special techniques are used depending on what is required for civil engineering structures. Therefore it is possible to transfer soil bioengineering techniques to "underdeveloped countries" but for the potential local bio-technical plants basic research is essential. Most of the mentioned projects focus primarily on plants to understand the technical and biological properties.

The two steps (plants and techniques) should be clearly separated as follows:

- The search for local plants with adequate characteristics to be used for this type of realization;

- Determinating best type of soil bioengineering technique in specific operational contexts (geotechnical characteristics and hydraulic aspects of the construction site, temperature and pluviometric conditions, socioeconomic issues).

The first results of the above-mentioned studies show, without any doubt, the practical possibility of employing these techniques in places with differing environmental, economical and social conditions, as opposed to the European context, where soil bioengineering has been developed.

Nevertheless, cost quantification for such interventions, compared to those referred to in conventional ones, for slope stabilization and riverbank protection, have almost the same importance as technical feasibility evalution.

A Previous study (Petrone and Preti, 2005), without work realization support, has shown the economic convenience of constructing a vegetated crib-wall (one of the most representative soil bioengineering works), as opposed to other solutions such as gabions (usually employed in Central America), or concrete walls.

Published by Copernicus Publications on behalf of the European Geosciences Union. 


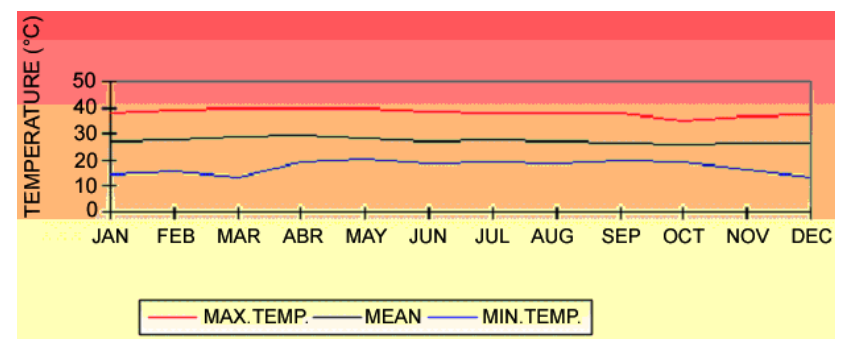

Fig. 1. Monthly mean maximum and minimum temperatures for the period 1975-2000 in León (www.ineter.gob.ni).

The present work experimentally investigates the plants to be used and considers economic efficiency of the proposed solutions.

\section{Materials and methods}

Experiments took place on two sites, both found in the city of León.

The Koppen climatic classification identifies the study area akin to the Tropical savanna. In particular, as regards the city of León, Figs. 1 and 2 (related to temperature and rain distribution), show the presence of two seasons, a dry one and a rainy one, with temperatures constantly above $20^{\circ}$. The soil is mainly of volcanic origin.

The choice of local plants to be used as shoots for soil bioengineering works comes from specific previous studies on this subject (Petrone and Preti, 2005), and also with interviews of local experts from León University (UNANLEON). A bibliographic research, based on texts and internet web sites has been carried out to complete and closely examine the collected information.

The following criteria has been used to choose the vegetal species:

- local plants;

- easily found in the area concerned;

- shoot propagation;

- high tolerance of differing soil conditions;

- not too large once adult.

With these factors in mind, the following species have been chosen:

- Madero negro (Gliricidia sepium);

- Tiguilote (Cordia dentata);

- Tempate (Jatropha curcas);

- Jinocuabo (Bursera simaruba).

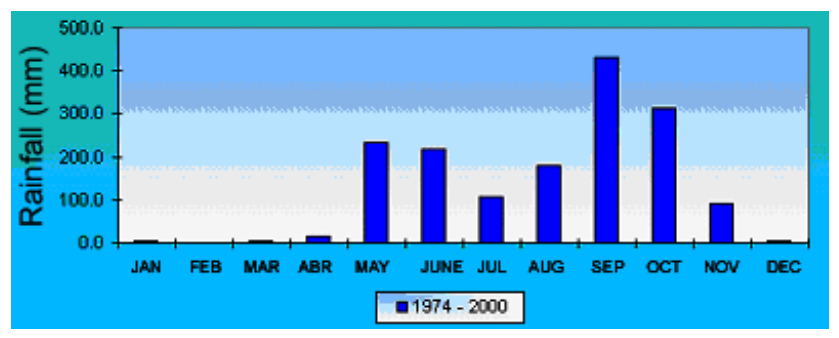

Fig. 2. Monthly mean precipitation for the period 1974-2000 in León (www.ineter.gob.ni).

The following is a brief description of the above-cited plants:

Gliricidia sepium is a member of the Fabaceae family, it is a small to medium-sized tree, reaching heights between 6 and $20 \mathrm{~m}$ (10 m on average), very common in Mexico and Central America, it grows well with a temperature of 20$30^{\circ} \mathrm{C}$, with precipitations between 900 and $1500 \mathrm{~mm}$ per year and a five month dry season, used for firewood, fodder and healing purposes (IRENA, 1992).

Cordia dentata is from the Boraginaceae family, a tree of between 2 and $10 \mathrm{~m}$ in height, native of Mexico it has now spread in all of South America, it lives in dry and stony sites, in clearcuts, at an altitude ranging from 0 to $900 \mathrm{~m}$, usually found at the base of slopes, it is appreciated in carpentry and in the ornamental sector for its beautiful flowers (IRENA, 1992).

Jatropha curcas derives from the Euphorbiaceae family, a small sized tree of between 4 and $8 \mathrm{~m}$ in height, native of Tropical America it is now widespread from southern Florida to Colombia, preferring temperatures of between 20 and $28^{\circ} \mathrm{C}$ and annual precipitations of $600-800 \mathrm{~mm}$, its seeds are well known in bio-fuel production and other parts of the plant can be used as fodder and curative purposes (IRENA, 1992).

Bursera simaruba derives from the Burseraceae family, a tree reaching $25-30 \mathrm{~m}$ in height, it can be found in Florida, Southern Mexico, Central America up to Panama and in the North-Western part of South America, it grows well with annual precipitations between 1000 and $3000 \mathrm{~mm}$ and mean temperatures between 18 and $28^{\circ} \mathrm{C}$, used in the carpentry sector and for medicine production (IRENA, 1992).

The plants used for the experiments were collected in León, being first placed in an area used as an experimental nursery and then transferred onto the riverbank protection.

The plantation area, owned by UNAN-LEON, is called "Finca del Ojoche" (Ojoche Farm), and it is normally used for fruit tree cultivation (especially bananas). Irrigation water access was the determining factor in choosing the "Finca del Ojoche" during nursey preparation. 


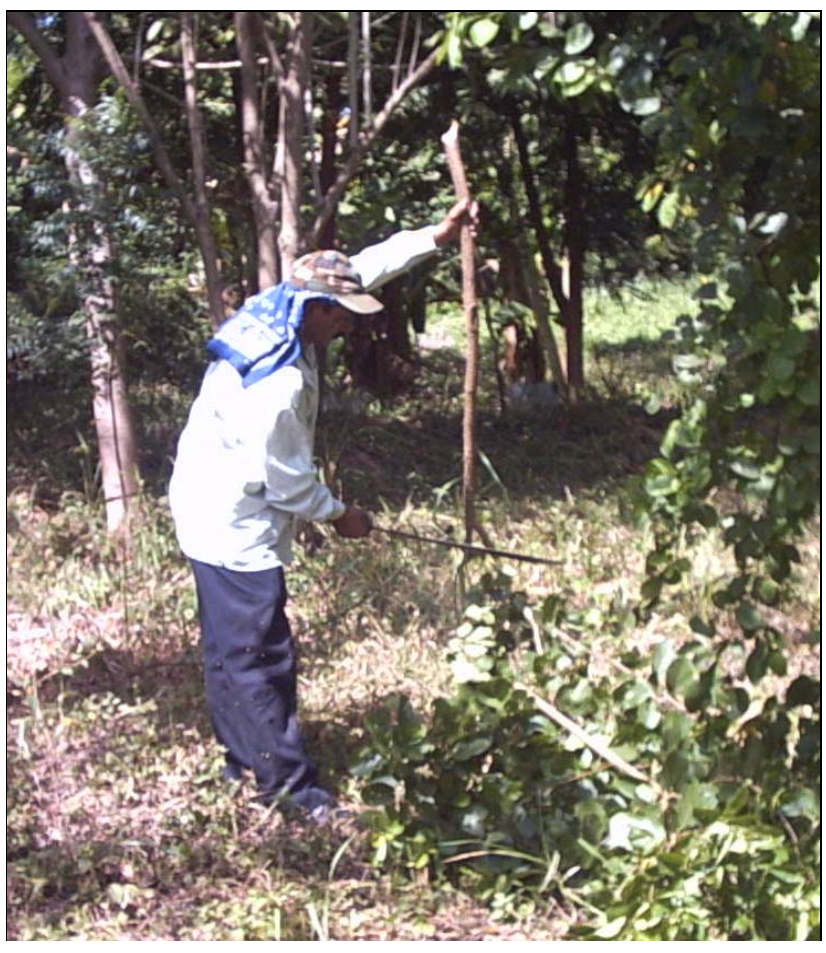

Fig. 3. Cuttings preparation phase with machete.

The tree samplings gathered were selected using on-thespot surveys of the León area, using UNAN-LEON vehicles. For each species, we collected 50 cuttings, in particular for Gliricidia sepium we gathered cuttings from 9 plants, for Cordia dentata from 10 plants, for Jatropha curcas from 7 plants and for Bursera simaruba from 4 plants. The unequal number of the plants could be a decisive factor for their survival rate. Having set a significant minimum number of plants per each species, we had to go a longer distance in order to carry out the sampling of the least common species (Bursera simaruba). Within a range which was equal to such a distance, we reckoned the number of plants per species we had to sample should have been proportional to their frequency. We deemed such a criterion could have been valid for assessing the use of the living material which was available in loco for use in soil bioengineering.

The cuttings were collected with the most commonly used farming instrument in Latin America, the machete (Fig. 3). Transport from the cutting site to the nursery was made with a small van, immediately after cutting.

The cuttings were planted by manually digging holes in the ground with a hoe and spade. The holes were $30 \mathrm{~cm}$ deep and spaced at almost $25 \mathrm{~cm}$ to simulate the execution phase of the work, and facilitating extraction without damaging surrounding plants. The cuttings were planted vertically (Fig. 4), even though it is well known that subhorizontal planting causes greater root mass and shoot production (Schiechtl, 1991), as we were planning to continue

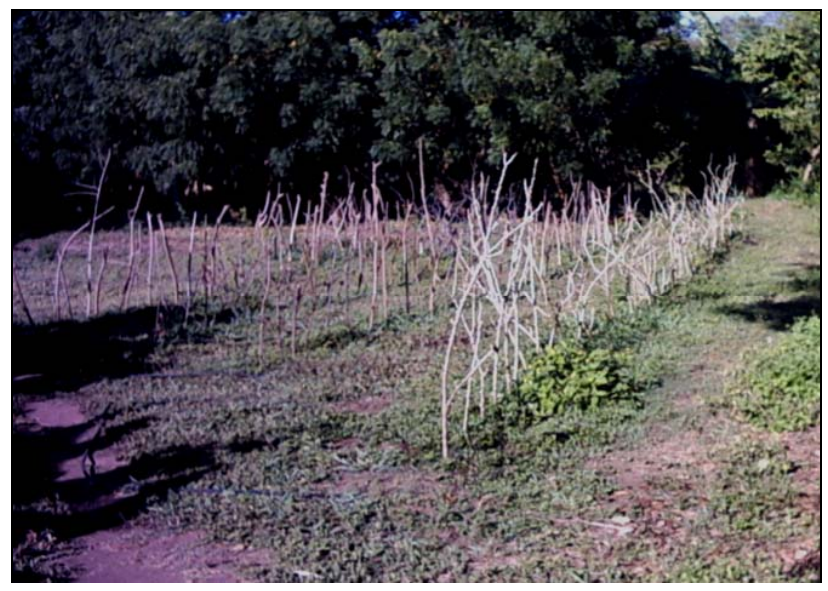

Fig. 4. Cuttings plantation.

the experiment by testing the plants regarding this aspect.

The cuttings were planted between the 10 and 11 December 2003. The most favourable rooting period in Nicaragua is during the rainy season, more precisely, from June to the end of August. In order to simulate these conditions we irrigated the plantation on a daily basis, and the water amount required for successful rooting has been determined taking into account the monthly mean precipitations of the most favourable months between 1974 and 2000 (Fig. 2).

In correspondence with the realization of the works, the plants were excavated and rooting percentage and vigour were evaluated. After which, between 28, 29 and 30 January, they were utilized in the construction of the riverbank protection constituted by a live vegetated crib wall and a slope grating. At the moment of extraction, the number of rooted plants or live ones were counted, then the cuttings were collocated in the riverbank protection and were irrigated until the beginning of the rainy season.

During the cutting collocation phase of the works, we arranged to distribute the four species in a homogeneous way, in order to guarantee the same conditions for their development. Cuttings, for a total of 200, have been placed on three ranks of the live crib wall, for a total of $30 \mathrm{~m}$ - with a planting out density of a specimen every $0.15 \mathrm{~m}$. Homogeneity of planting out was achieved by alternating a species with another by repeating the sequence Gliricidia sepium, Cordia dentata, Jatropha curcas, Bursera simaruba.

Work progress was monitored during the year by taking pictures and measurements: the first monitoring was in $\mathrm{Au}-$ gust of the first year (in the middle of the rainy season), and the second one in May 2005 (at the end of the dry season). In these operations we counted the surviving cuttings and also terminal shoot length and diameter, in order to collect information about the growth rate and to carry out statistical comparative tests (chi-square) between the different species.

As far as the first one is concerned it is important to assess this parameter in order to privilege species with higher 

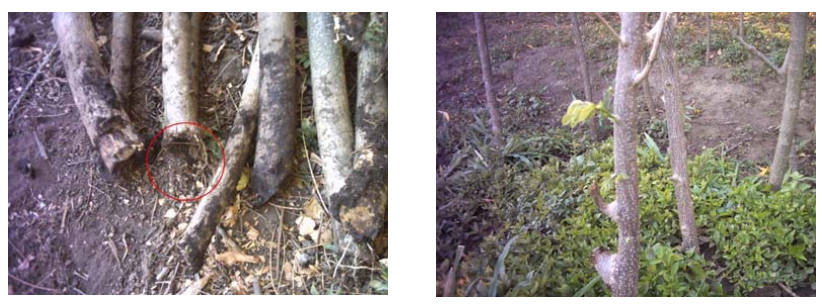

Fig. 5. Gliricidia sepium cuttings after and before excavation.

values. According to Schluter (1971, in Lammeraner et al., 2005), for example, only plants with survival rates of at least $70 \%$ should be considered for use in soil bioengineering practice. As far as the second parameter is concerned, the relationship between shoot and root development allows estimation of overall rooting performance and consequently, the anchoring and soil binding functions of the plants (Lammeraner et al., 2005). Not only is the measure of the third parameter needed in order to assess the degree of vegetative development of the plant, but it is needed above all to understand how long will the shoot remain flexible: in fact, in case of intervention on the bank of a river it is of vital importance that shoots keep their flexibility and bend themselves to the running water without making resistance. It is generally considered that a $4 \mathrm{~cm}$. diameter constitute the upper limit for not losing flexibility. Substantially, measurement of the development of the shoot diameter provides a fundamental information on how frequently to perform felling operations.

On the base of the data obtained, we decided to perform two tests in order to confirm or deny the following hypotheses:

- there are no differences among the survival rates of the three best performing species;

- the difference in terms of survival rate between the worst performing species and the other ones is not accidental.

A final qualitative monitoring was carried out during October 2007, in order to evaluate the intervention area's evolution after almost four years.

A cost analysis has been carried out in order to evaluate the economic sustainability of the soil bioengineering intervention. To perform this we looked for local price of the materials and manpower. In order to have a more objective value, once the unit price was calculated for the works, we then proceeded to the conversion in PPP Dollars (Purchasing Power Parity Dollar). The PPP Dollar is an artificial dollar, having the same purchasing power in all countries, as its value has been calculated by the pondered means of worldwide prices of 151 goods categories. This tool is currently used by International Agencies, for example, UNDP, (UNDP, 2006) and

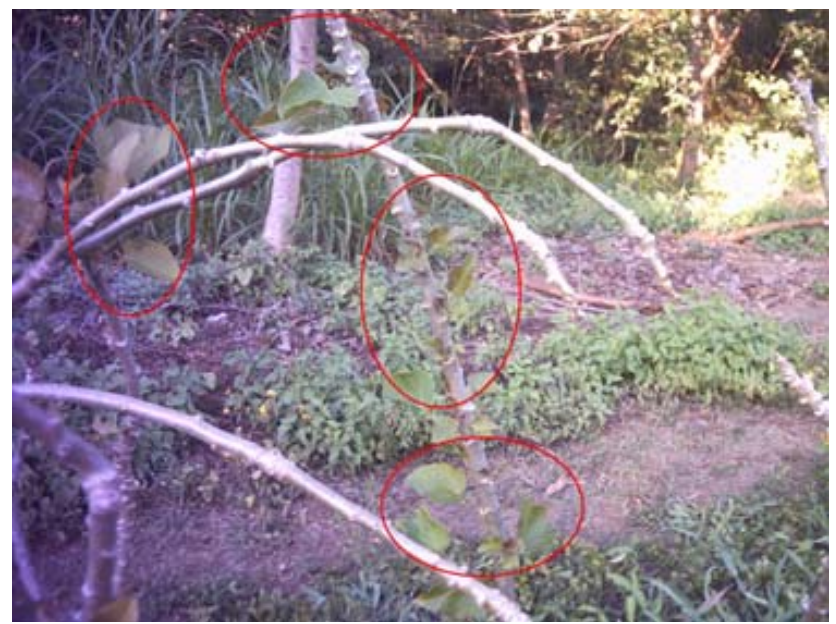

Fig. 6. Jatropha curcas cuttings: the foliar system growth.

the International Monetary Fund. In this way we can compare prices paid in different geographic areas worldwide and understand their real entity.

\section{Results}

3.1 First monitoring (extraction from experimental nursery)

\subsubsection{Gliricidia sepium}

In the initial phase we planted 50 cuttings (the same amount for all four species), of $160 \mathrm{~cm}$ mean length and $6 \mathrm{~cm}$ mean diameter. At the moment of extraction, we found a survival rate of $76 \%$ (Table 1 and Fig. 9). In fact 38 cuttings could be transplanted, some with roots of almost $1 \mathrm{~cm}$ in length and many with small leaves (Fig. 5).

Dimensional parameters are currently no different to the ones at plantation time.

\subsubsection{Cordia dentata}

When the "tiguilote" (Cordia dentata) was extracted it showed well-formed foliar systems and its survival rate was of $62 \%$ ( 31 cuttings out of 50; Table 1 and Fig. 9). The mean length was $140 \mathrm{~cm}$ and mean diameter of $5 \mathrm{~cm}$. The presence of small roots at the cuttings' base were noticeable.

This species' cuttings were characteristically vital and gathered near the nursery.

\subsubsection{Jatropha curcas}

"Tempate" showed foliar systems in almost every cutting, being without any doubt the species in best condition (Fig. 6). 
Table 1. Survival rate and root system condition at the extraction from the nursery.

\begin{tabular}{lcccl}
\hline Specie & Planted cuttings & Survived cuttings & Survival rate & Roots condition \\
\hline Gliricidia sepium & 50 & 38 & $76 \%$ & Present but not very developed \\
Cordia dentata & 50 & 31 & $62 \%$ & Not very developed or absent \\
Jatropha curcas & 50 & 45 & $90 \%$ & Well developed \\
Bursera Simaruba & 50 & 17 & $34 \%$ & Not very developed or absent \\
\hline
\end{tabular}

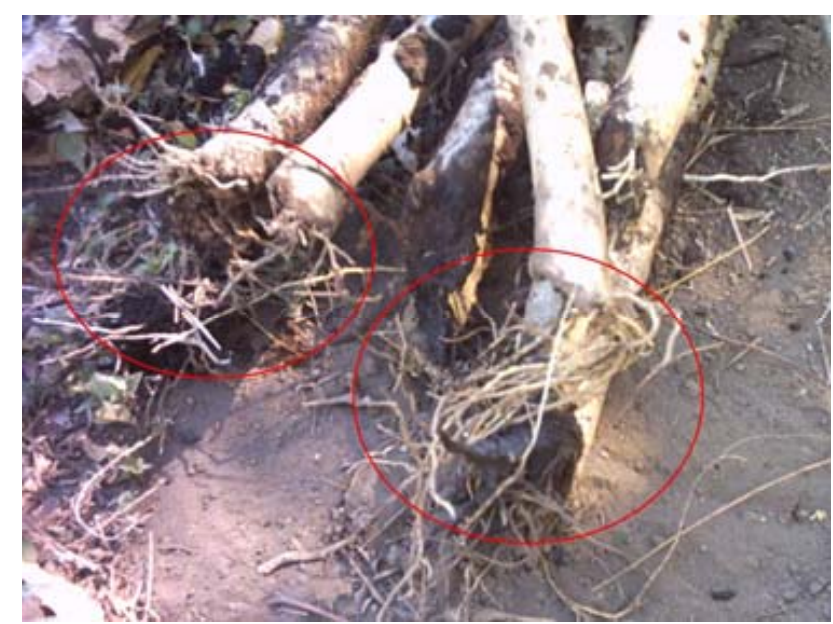

Fig. 7. Detail of root system growth of Jatropha curcas cuttings at extraction.

The mean length and diameter were of $150 \mathrm{~cm}$ and $5.5 \mathrm{~cm}$ respectively, survival rate was of $90 \%$ (Table 1 and Fig. 9), 45 cuttings were later used for riverbank protection construction.

Jatropha curcas' root system was the best developed, for both number and length of radicles (Fig. 7).

This species' cuttings were in excellent condition, with a high growth rate and vitality.

\subsubsection{Bursera simaruba}

Jinocuabo plants (Bursera simaruba) showed less vitality compared to other species, they did not have leaves and only a few rooted (radicles remained small), survival rate was of $34 \%$ (Table 1 and Fig. 9).

Initially, the cuttings had a mean length of $140 \mathrm{~cm}$ and a mean diameter of $4 \mathrm{~cm}$.

The following table resumes the recorded data that, compared to those referred to other species, point out the stress undergone by Bursera simaruba. If we perform a chi-square test (one degree of freedom and Yates' correction), with the data referred to in Cordia dentata and Bursera simaruba, we

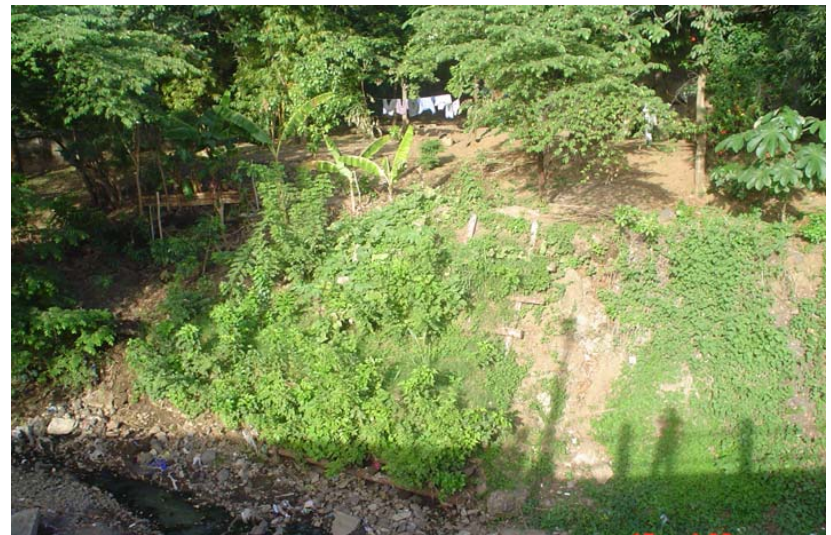

Fig. 8. The riverbank protection (live vegetated crib wall and a slope grating) 7 months after cuttings planted.

obtain a value of 7.30; consequently, we can say with more than $99 \%$ probability that the difference between the two survival rates is not accidental.

\subsection{Second monitoring, 28 August 2004}

The second monitoring (Table 2 and Fig. 9) was dated at the end of August 2004 during the rainy season, the best period for vegetation growth (Fig. 8).

Seven months have passed since the cuttings' plantation. We found excellent survival rates for Gliricidia sepium (33 cuttings out of 38), Cordia dentata (25 out of 31) and Jatropha curcas (34 out of 45). Bursera simaruba continued with an unsatisfactory survival rate (only 5 cuttings out of 17).

The evolution of parameters related to the vegetative development (mean length and diameter of the shoots), underlines the selected species' enhancement rapidity, characteristically typical of tropical plants.

\subsection{Third monitoring, 5 May 2005}

The third monitoring (Table 3 and Fig. 9) occurred in May 2005 (more than a year after the work's construction), when the dry season was ending and therefore, during the period of highest water stress. As shown in Table 3 and in Fig. 9, 
Table 2. Survival rate and growth parameters of the cuttings at the second monitoring.

\begin{tabular}{lccc}
\hline & N. of survived cuttings & Mean diameter of cuttings $(\mathrm{cm})$ & Shoots mean length $(\mathrm{cm})$ \\
\hline Gliricidia sepium & 33 & 9.0 & 199.1 \\
Cordia dentata & 25 & 7.8 & 166.8 \\
Jatropha curcas & 34 & 7.7 & 161.7 \\
Bursera simaruba & 5 & 7.0 & 154.0 \\
\hline
\end{tabular}

Table 3. Survival rate and growth parameters of the cuttings at the final monitoring.

\begin{tabular}{lccc}
\hline & N. of survived cuttings & Mean diameter of cuttings $(\mathrm{cm})$ & Shoots mean length $(\mathrm{cm})$ \\
\hline Gliricidia sepium & 25 & 10,0 & 211.6 \\
Cordia dentata & 18 & 8.3 & 178.9 \\
Jatropha curcas & 24 & 8.8 & 179.9 \\
Bursera simaruba & 0 & $/$ & $/$ \\
\hline
\end{tabular}

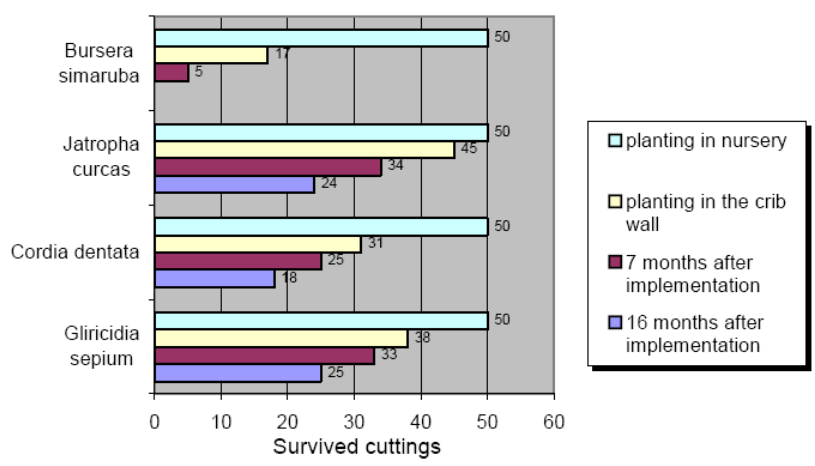

Fig. 9. Diagram of survival rate trend for planted cuttings.

Gliricidia sepium and Jatropha curcas registered (during the third monitoring) an elevated number of survived cuttings, respectively 25 and 24 .

The surviving Cordia dentata cuttings were 18, and presented a growth rate similar to that of Jatropha curcas.

At this moment no living cutting of Bursera simaruba was found.

Figure 9 underlines the surviving rate trend of the four tested species.

\subsection{Final monitoring, 11 October 2007}

The final monitoring occurred in October 2007 (almost four years after the work's construction), at the end of the wet season. In the upper part of the work, the terminal shoots are longer than $3 \mathrm{~m}$ with a diameter of more than $4 \mathrm{~cm}$.

\subsection{Work's cost}

The calculated cost of a vegetated live crib wall in Nicaragua is almost 15 euro $/ \mathrm{m}^{3}$ whilst in Italy, we can consider spending 230 euro/m $\mathrm{m}^{3}$ (Regione Lazio, 2002), 15 times as much.

This difference is partially caused by manpower costs, which are 30 times less in Nicaragua than in Italy, mitigated by a lower variance concerning other budget lines (materials and rents).

Using the PPP Dollar, we can say that a vegetated live crib wall in Nicaragua costs almost 90 PPP\$, whilst in Italy almost 270 PPP\$.

\section{Discussion}

The behaviour of Gliricidia sepium and Jatropha curcas is quite similar to one another, even though the first one presents a slightly higher growth rate.

Indeed, Gliricidia sepium is the most widespread species in the surrounding area, and the most recommended by local experts, especially because of its tolerance of unfavourable soil and climatic conditions. The not-excellent productivity of Cordia dentata, considered to be one of the most promising according to both literature (CATIE, 1998; IRENA, 1992), and local experts, could be related to the fact that it is not a true hydric species albeit a local one. The application of the chi-square comparative test between Gliricidia sepium, Cordia dentata and Jatropha curcas cannot exclude that survival rate differences are accidental.

The only plant which didn't survive at all is Bursera simaruba; from the moment of nursery sampling, this plant had a characteristically low growth rate and adventitious rooting ability. 
In regard to climatic conditions, their influence could not be negative, because cuttings were drawn from an area whose conditions were equivalent. According to bibliographical sources Bursera simaruba is a specie which can be found in a wide variety of climates and soil conditions. In Nicaragua, it is located in the subtropical dry-area, subtropical dampwood area (warm and temperate), subtropical very-dampwood and subtropical low mountain wood, at heights of from 0 to $1100 \mathrm{~m}$. In regard to soil conditions, it can adapt to a wide variety of soils, including chalky and rocky ones, it grows quite rapidly in deep soils, of a texture which ranges from sandy-loam to clay-loam. In spite of this we have to stress that this specie is less widespread than the others in the project area, as above mentioned. In our case study it cannot be excluded the effect of the competition with the other three species.

Amongst the various possible causes of failure for this species, could be "transporting damage", the sample site for Bursera simaruba cuttings was, for instance, the furthest away with respect to the others. In fact damage during transportation is acknowledged by those who deal with soil bioengineering as one of the most frequent causes of low survival rates.

The final qualitative monitoring shows that the area was well covered by planted vegetation. Current survival rate measures are meaningless, due to the heavy sedimentation process which has occurred at the base of the living crib wall (Fig. 10). In the upper part of the riverbank it would be necessary to proceed to a general shoot cutting in order to maintain flexibility.

The on-going experience of realizing soil bioengineering works in Nicaragua, confirms not only the obvious low cost, compared to similar interventions realised in Europe, but also in comparison to classical stabilization works.

In fact previous studies (Petrone and Preti, 2005) have pointed out that construction typologies largely used in loco, such as the gabions, are economically unfavourable; it is sufficient to say that a single gabion $(2 \mathrm{~m} \times 1 \mathrm{~m} \times 1 \mathrm{~m})$ costs almost 40 euro, without considering transport and construction costs.

Moreover the PPP Dollar approach confirms the economic efficiency of soil bioengineering works, even if we consider the specific operational context.

\section{Conclusions}

The investigation of local species' suitability for soil bioengineering works is of great importance for their success. The results of the present paper show a satisfactory behaviour, regarding both survival and growth rates for three local species commonly found in Nicaragua, Gliricidia sepium, Cordia dentata and Jatropha curcas.

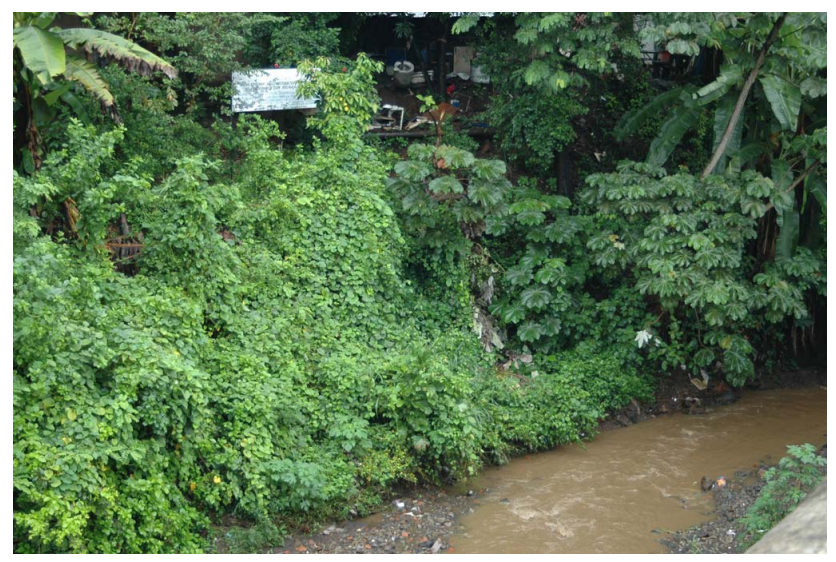

Fig. 10. The riverbank protection (live vegetated crib wall and a slope grating) 44 months after cuttings planted and with sedimentation in the lower part.

Further investigations on this work, and others realized, in both dry and humid tropical areas, are in progress evaluating different species suitability.

Realization costs justify the efforts made until now for promoting soil bioengineering diffusion in underdeveloped countries, these techniques should become the most effective and sustainable way of mitigating the increasing inundation and landslide risk in over-exploited watershed.

Acknowledgements. The realization of the riverbank protection was financed by the Tuscan Region Government (Italy) and by León Municipality (Nicaragua). A special thanks for the technical support given by the Biology Department of UNAN-LEON, Roberto Ferrari and Piero Matassoni. The research was financed by a PRIN-MIUR (Italian Ministry for University and Research) Project.

Edited by: N. Romano

\section{References}

Centro Agronomico Tropical de Investigacion y Enseñanza (CATIE): Cordia dentata Poiret, Proyecto Semillas Forestales (PROSEFOR), Nota técnica sobre manejo de semillas forestales, 49, 2 pp., Costa Rica, 1998.

Ferrari, R., Petrone, A., and Preti, F.: La Riscoperta dell'America, ACER, 5(5), 74-79, 2005.

Florineth, F.: in: Stabilization of gullies with soil - bio-engineering methods in the Alps and in Nepal, edited by: Yong, Li, Poisen, J., and Valentin, C., Gully Erosion under Global Change, 315-339, Sichuan Science and Technology Press, Chengdu, China, 2004.

Ghimire, S. K. and Karki, K. K.: Mitigation of soil erosion hazards through bioengineering: a case study of Mid-Himalaya, Nepal, in: Eco- and Ground Bio-Engineering: The Use of Vegetation to Improve Slope Stability, edited by: Stokes, A., Spanos, I., Norris, J. E., Cammeraat, L. H., Proceedings of the First International Conference on Eco-engineering 13-17 September 2004, Thessaloniki, Greece, Developments in Plant and Soil Sciences 103, 
Springer, Dordrecht. ISBN-10:1-4020-5592-7; ISBN-13: 978-14020-5592-8, 2007.

IRENA: Arboles forsestales utiles para su propagacion, Instituto Nicaraguense de Recursos Naturales y del Ambientes, Managua, Nicaragua, 246 pp., 1992.

Lammeraner, W., Rauch, H. P., and Laaha, G.: Implementation and monitoring of soil bioengineering measures at a landslide in the Middle Mountains of Nepal, Plant and Soil, 278, 159-170, 2005.

Petrone, A. and Preti, F.: Ingenieria Naturalistica en Centroamérica, Manuali Tecnici per la Cooperazione allo Sviluppo, Istituto Agronomico per l'Oltremare, Società Editrice Fiorentina, Firenze, 108 pp., ISBN 88-89507-02-0, 2005.

Petrone, A., Matassoni, P., and Preti, F.: Sperimentazioni con talee di specie autoctone in interventi di ingegneria naturalistica in Nicaragua, Quaderni di Idronomia montana, 26, 477-488, Nuova Editrice Bios, Castrolibero, 2006.

Rauch, H. P., Belihart, S., Ertl, D., Lammeranner, W., and Wibmer, S.: Implementation and Monitoring of BioEngineering Measures at a Landslide in the Middle Mountains of Nepal, in: Eco- and
Ground Bio-Engineering: The Use of Vegetation to Improve Slope Stability, edited by: Stokes, A., Spanos, I., Norris, J. E., Cammeraat, L. H., Proceedings of the First International Conference on Eco-engineering 13-17 September 2004, Thessaloniki, Greece. Developments in Plant and Soil Sciences, 103, Springer, Dordrecht. ISBN-10: 1-4020-5592-7; ISBN-13: 978-1-40205592-8, 2007.

Regione Lazio, Assessorato per l'Ambiente: Manuale di Ingegneria Naturalistica applicabile al settore idraulico. Ed. Punto Stampa s.r.l., Roma., 421 pp., 2002

Schiechtl, H. M.: Bio-ingegneria forestale, Edizioni Castaldi, Feltre (Belluno), 263 pp., 1991.

Sutili, F. J., Durlo, M. A., and Bressan, D. A.: Bio-technical capability of "sarandi-branco" (Phyllanthus sellowianus mull. Arg.) and "vime" (Salix viminalis L.) for re-vegetation water corse edges, Ciencia Florestal, 14(1), 13-20, ISSN 0103-9954, Santa Maria, Brasile, 2004.

UNDP (United Nations Development Programme): Lo sviluppo umano rapporto 2006 - L'acqua 10 tra potere e poverta, Legoprint, Lavis (Trento), 494 pp., ISBN 88- 7885-099-3, 2006. 